\title{
W+Rh as Permanent Chemical Modifier in Simultaneous Atomic Absorption Spectrometry: Interference Studies on As, Cd, Pb and Se Determination
}

\author{
Cassiana S. Nomura, Paulo R. M. Correia, Pedro V. Oliveira* and Elisabeth Oliveira \\ Instituto de Química, Universidade de São Paulo, CP 26077, 05513-970 São Paulo - SP, Brazil
}

\begin{abstract}
Um estudo sistemático para verificar as interferências provocadas por $\mathrm{Na}^{+}, \mathrm{K}^{+}, \mathrm{Ca}^{2+}, \mathrm{Mg}^{2+}, \mathrm{Cl}^{-}$,

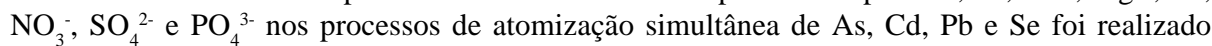
utilizando um espectrômetro de absorção atômica com atomização eletrotérmica. A mistura de $250 \mu \mathrm{g} \mathrm{W}+250 \mu \mathrm{g} \mathrm{Rh}$ foi termicamente depositada sobre a plataforma do tubo de grafite e utilizada como modificador químico permanente. $\mathrm{O}$ ajuste compromissado dos parâmetros do programa de aquecimento $\left(\mathrm{Tp}=650^{\circ} \mathrm{C}\right.$ e Ta $\left.=2200{ }^{\circ} \mathrm{C}\right)$ diminuiu a eficiência de decomposição e volatilização térmica de alguns interferentes durante a etapa de pirólise, tornando a atomização simultânea de As, $\mathrm{Cd}, \mathrm{Pb}$ e Se mais suscetível à interferências. Os ânions $\mathrm{Cl}^{-}$e $\mathrm{SO}_{4}^{2-}$ causaram as interferências mais severas, enquanto $\mathrm{NO}_{3}^{-}$somente afetou a atomização dos elementos estudados quando presente em elevadas quantidades ( $>27 \mu \mathrm{g}$ ). O ânion $\mathrm{PO}_{4}^{3-}$ provocou uma forte interferência negativa sobre o Se. As interferências causadas pelos cátions $\mathrm{Na}^{+}, \mathrm{K}^{+}, \mathrm{Mg}^{2+}, \mathrm{Ca}^{2+}$ afetaram principalmente o $\mathrm{Cd}$, sendo que os cloretos dessas espécies provocaram interferências mais intensas do que os nitratos.
\end{abstract}

A systematic study of $\mathrm{Na}^{+}, \mathrm{K}^{+}, \mathrm{Ca}^{2+}, \mathrm{Mg}^{2+}, \mathrm{Cl}^{-}, \mathrm{NO}_{3}^{-}, \mathrm{SO}_{4}{ }^{2-}$ and $\mathrm{PO}_{4}{ }^{3-}$ interference on the simultaneous atomization of $\mathrm{As}, \mathrm{Cd}, \mathrm{Pb}$ and $\mathrm{Se}$ was carried out using an electrothermal atomic absorption spectrometer. The mixture $250 \mu \mathrm{g} \mathrm{W}+250 \mu \mathrm{g}$ Rh was thermally deposited on the graphite tube platform and used as permanent chemical modifier. The compromised heating program adjustments $\left(\mathrm{Tp}=650^{\circ} \mathrm{C}\right.$ and $\left.\mathrm{Ta}=2200{ }^{\circ} \mathrm{C}\right)$ diminished the thermal decomposition and volatilization efficiency of the interfering species during the pyrolysis step. The $\mathrm{Cl}^{-}$and $\mathrm{SO}_{4}{ }^{2-}$ anions caused the most severe interference, while $\mathrm{NO}_{3}^{-}$only affected the analytes' atomization when high amounts $\left(>27 \mu \mathrm{g}\right.$ ) were used. The anion $\mathrm{PO}_{4}^{3-}$ produced a strong negative interference on the Se absorbance signals. The presence of $\mathrm{Na}^{+}, \mathrm{K}^{+}, \mathrm{Ca}^{2+}$ and $\mathrm{Mg}^{2+}$ prejudiced mainly $\mathrm{Cd}$, and the interference effects of $\mathrm{Cl}^{-}$salts were more pronounced than $\mathrm{NO}_{3}^{-}$salts.

Keywords: simultaneous atomic absorption spectrometry, interference, permanent chemical modifier

\section{Introduction}

Among the instrumental techniques available for trace and ultra-trace element determinations, atomic absorption spectrometry (AAS) occupies an outstanding position due to its high specificity, selectivity, and sensitivity, low spectral interference, and ease of operation. Despite of these attributes, its conventional mono-element operation mode restrains the analytical frequency and can be considered as the main drawback of this technique. ${ }^{1}$ This shortcoming is aggravated for electrothermal atomic absorption spectrometry (ETAAS) due to the long extent of the heating program atomizer, typically 1 to $3 \mathrm{~min}$.

*e-mail: pvolivei@iq.usp.br
Multi-element atomic absorption researches have aroused interest since the first AAS stage in order to conceive a spectrometer able to determine several elements simultaneously or quasi simultaneously. As result of these efforts, the simultaneous atomic absorption spectrometry (SIMAAS) technique was proposed. ${ }^{2-4}$ Commercially introduced during the last decade, SIMAAS adjoined the multi-element capability for atomic absorption spectrometry, reducing time and costs associated with the analysis. Indeed, expressive advantages are obtained even when the spectrometer is operated in 2-element simultaneous mode: the sample and high purity reagent requirements, and the residue generation are almost reduced in $50 \%$, while the analytical frequency and the analytical results obtained with the same graphite tube are almost duplicated. 
At the present, the most updated commercial instrumentation is a line-source simultaneous spectrometer, ${ }^{1}$ equipped with transversely heated graphite atomizer with integrated platform, Zeeman-effect background corrector, and solid-state detector, making possible the operation under STPF conditions. ${ }^{5}$ This instrument allows simultaneous determinations up to six elements. ${ }^{1}$

SIMAAS has been used for various multi-element determinations with acceptable performance ${ }^{6-26}$ (Table 1), keeping the main features of ETAAS: high sensitivity, low detection limits, reduced sample requirements, and the possibility to carry out in situ sample decomposition inside the graphite furnace. Although the increase number of multi-element procedures, reports dealing with interference studies for SIMAAS are scare so far. ${ }^{12}$

The mixture palladium and magnesium nitrate has been widely used for multi-element determinations by SIMAAS. ${ }^{6,8-11,14,15,20,23,25}$ It is claimed as universal chemical modifier due to the thermal stability improvement for 21 elements. ${ }^{27}$ Although this mixture seems to be the most suitable choice, other alternatives as rhodium-based chemical modifiers can also be explored for multi-element determinations.

The rhodium-based chemical modifiers have been successfully adopted for mono-element determinations by ETAAS. The mixture of $250 \mu \mathrm{g} \mathrm{W}+200 \mu \mathrm{g} \mathrm{Rh}$ was proposed as permanent chemical modifier for monoelement determinations. ${ }^{28-31}$ The results indicated its effectiveness for $\mathrm{As}, \mathrm{Cd}, \mathrm{Cu}, \mathrm{Pb}$ and $\mathrm{Se}$, and its performance is equal or superior than that verified for the universal chemical modifier.

The use of permanent chemical modifiers allows increase the graphite tube lifetime, eliminate volatile impurities during the thermal coating process, decrease the detection limits, reduce the total heating cycle time, and minimize the high purity chemical consumption. ${ }^{28}$

Considering these favorable characteristics, the aim of this work is to investigate the performance of the permanent chemical modifier $250 \mu \mathrm{g} \mathrm{W}+250 \mu \mathrm{g}$ Rh to minimize interferences of $\mathrm{Na}^{+}, \mathrm{K}^{+}, \mathrm{Ca}^{2+}, \mathrm{Mg}^{2+}, \mathrm{NO}_{3}^{-}, \mathrm{Cl}^{-}, \mathrm{SO}_{4}^{2-}$ and $\mathrm{PO}_{4}{ }^{3}$ on the simultaneous atomization of $\mathrm{As}, \mathrm{Cd}, \mathrm{Pb}$ and $\mathrm{Se}$. Additionally, determinations of $\mathrm{As}, \mathrm{Cd}, \mathrm{Pb}$ and $\mathrm{Se}$ in non-potable water using this chemical modifier are proposed.

\section{Experimental}

\section{Apparatus}

Measurements were carried out by using a SIMAA6000 electrothermal atomic absorption spectrometer with a longitudinal Zeeman-effect background correction system, Echelle optical arrangement, solid state detector and standard THGA tube with pyrolytic coated integrated platform (Perkin-Elmer, Norwalk, CT, USA).

The spectrometer was operated in 4-element simultaneous mode using electrodeless discharge lamps for $\operatorname{arsenic}(\lambda=193.7 \mathrm{~nm}, \mathrm{i}=380 \mathrm{~mA})$, cadmium $(\lambda=228.8 \mathrm{~nm}$, $\mathrm{i}=200 \mathrm{~mA})$, lead $(\lambda=283.3 \mathrm{~nm}, \mathrm{i}=450 \mathrm{~mA})$, and selenium $(\lambda=196.0 \mathrm{~nm}, \mathrm{i}=290 \mathrm{~mA})$. Solutions were delivered into the graphite tube by means of an AS-72 autosampler.

Argon 99.999\% v/v (Air Liquide Brasil S/A, São Paulo, SP, Brazil) was used as protective and purge gas.

\section{Reagent and reference solutions}

All solutions were prepared with high purity de-ionized water $(18.2 \mathrm{M} \Omega \mathrm{cm})$ obtained from a Milli-Q water purification system (Millipore Corp., Bedford, MA, USA). Analytical reagent-grade $\mathrm{HNO}_{3}$ (Synth, Diadema, SP, Brazil) was distilled in quartz sub-boiling stills (Marconi, Piracicaba, SP, Brazil). High purity standard reference solutions of arsenic $\left(\mathrm{As}_{2} \mathrm{O}_{3}\right)$, cadmium $\left(\mathrm{CdCl}_{2}\right)$, lead $\left[\mathrm{Pb}\left(\mathrm{NO}_{3}\right)_{2}\right]$ and selenium $\left(\mathrm{SeO}_{2}\right)$ from Tritisol (Merck, Darmstadt, Germany) were used to prepare the reference analytical solutions. The chemical modifier solutions were obtained from $\mathrm{Na}_{2} \mathrm{WO}_{4} \cdot 2 \mathrm{H}_{2} \mathrm{O}$ (Merck) and $\mathrm{RhCl}_{3}$ (Aldrich).

Cation and anion interference effects were investigated with solutions containing up to $10000 \mathrm{mg} \mathrm{L}^{-1}$ of $\mathrm{Na}^{+}$ $\left[\mathrm{NaNO}_{3}, \mathrm{NaCl}, \mathrm{Na}_{3} \mathrm{PO}_{4}\right.$ or $\mathrm{Na}_{2} \mathrm{SO}_{4}$ (Merck)], $10000 \mathrm{mg} \mathrm{L}^{-1}$ of $\mathrm{K}^{+}\left[\mathrm{KNO}_{3}\right.$ or $\mathrm{KCl}$ (Merck)], $5000 \mathrm{mg} \mathrm{L}^{-1}$ of $\mathrm{Ca}^{2+}\left[\mathrm{Ca}\left(\mathrm{NO}_{3}\right)_{2}\right.$ or $\mathrm{CaCl}_{2}$ (Merck) $]$ and $5000 \mathrm{mg} \mathrm{L}^{-1}$ of $\mathrm{Mg}^{2+}\left[\mathrm{Mg}\left(\mathrm{NO}_{3}\right)_{2}\right.$ or $\mathrm{MgCl}_{2}$ (Merck)] in $0.1 \% \mathrm{v} / \mathrm{v} \mathrm{HNO}_{3}$.

Arsenic, $\mathrm{Cd}, \mathrm{Pb}$ and $\mathrm{Se}$ were simultaneously determined in non-potable water samples with high saline content from Quality Technologies Pty Ltd (Mount Isa, Australia) using $250 \mu \mathrm{g} \mathrm{W}+250 \mu \mathrm{g} \mathrm{Rh}$ as permanent chemical modifier. The samples were diluted $1: 10$ or $1: 20$ with $0.1 \% \mathrm{v} / \mathrm{v} \mathrm{HNO}_{3}$ for the multi-element determinations. Addition and recovery tests were performed to verify the reliability of the obtained results for $\mathrm{As}, \mathrm{Cd}, \mathrm{Pb}$ and Se determination.

\section{Procedure}

All glassware, polypropylene flasks and bottles (Nalge Company, Rochester, USA) were cleaned with detergent solution, soaking in $10 \% \mathrm{v} / \mathrm{v} \mathrm{HNO}_{3}$ for $24 \mathrm{~h}$, rinsed with Milli-Q water and stored into a closed polypropylene container.

Solution manipulations were conducted in a class-100 laminar flow bench (Veco, Campinas, Brazil) to avoid airborne contamination. Reference solutions containing 
Table 1. Multi-element analytical procedures developed by SIMAAS

\begin{tabular}{|c|c|c|c|c|c|}
\hline Element & Sample & Chemical modifier & $\mathrm{LD}\left(\mathrm{mg} \mathrm{L}^{-1}\right)$ & $m_{0}(\mathrm{pg})$ & Ref \\
\hline $\begin{array}{l}\mathrm{Mn} \\
\mathrm{Se}\end{array}$ & Serum & $\mathrm{Pd}+\mathrm{Mg}$ & $\begin{array}{l}0.65 \\
5.0\end{array}$ & $\begin{array}{l}6.0 \\
46\end{array}$ & 6 \\
\hline $\begin{array}{l}\mathrm{Cu} \\
\mathrm{Fe} \\
\mathrm{Zn}\end{array}$ & Serum & - & $\begin{array}{l}4.0 \\
2.2 \\
0.4\end{array}$ & $\begin{array}{l}26 \\
16 \\
2.7\end{array}$ & 7 \\
\hline $\begin{array}{l}\mathrm{As} \\
\mathrm{Cu} \\
\mathrm{Mn} \\
\mathrm{Sb} \\
\mathrm{Se}\end{array}$ & Drinking water & $\mathrm{Pd}+\mathrm{Mg}$ & $\begin{array}{l}0.7 \\
0.2 \\
0.6 \\
0.3 \\
0.9\end{array}$ & $\begin{array}{l}39 \\
17 \\
60 \\
43 \\
45\end{array}$ & 8 \\
\hline $\begin{array}{l}\mathrm{Al} \\
\mathrm{As} \\
\mathrm{Cu} \\
\mathrm{Fe} \\
\mathrm{Mn} \\
\mathrm{Ni}\end{array}$ & Fuel ethanol & $\mathrm{Pd}+\mathrm{Mg}$ & $\begin{array}{l}1.2 \\
2.5 \\
0.2 \\
1.6 \\
0.2 \\
1.1\end{array}$ & $\begin{array}{l}37 \\
73 \\
31 \\
16 \\
45 \\
9.0\end{array}$ & 9 \\
\hline $\begin{array}{l}\mathrm{Bi} \\
\mathrm{Pb}\end{array}$ & Wine & $\mathrm{Pd}+\mathrm{Mg}$ & $\overline{0.9}$ & - & 10 \\
\hline $\begin{array}{l}\mathrm{Cu} \\
\mathrm{Mn} \\
\mathrm{Mo}\end{array}$ & Sea water & $\mathrm{Pd}+\mathrm{Mg}$ and $5 \% \mathrm{H}_{2}$ & $\begin{array}{l}0.4 \\
0.7 \\
1.2\end{array}$ & $\begin{array}{l} \\
- \\
-\end{array}$ & 11 \\
\hline $\begin{array}{l}\mathrm{Cr} \\
\mathrm{Mn}\end{array}$ & Urine & $\mathrm{Mg}$ & $\begin{array}{l}0.08 \\
0.16\end{array}$ & $\begin{array}{l}7.8 \\
4.6\end{array}$ & 13 \\
\hline $\begin{array}{l}\mathrm{Cd} \\
\mathrm{Pb}\end{array}$ & Wine & $\mathrm{Pd}+\mathrm{Mg}$ & $\begin{array}{c}0.03 \\
0.8\end{array}$ & $\begin{array}{l}0.6 \\
33\end{array}$ & 14 \\
\hline $\begin{array}{l}\mathrm{As} \\
\mathrm{Cd} \\
\mathrm{Ni} \\
\mathrm{Pb}\end{array}$ & Atmosferic particulate matter & $\mathrm{Pd}+\mathrm{Mg}$ & $\begin{array}{c}0.26 \\
0.02 \\
0.97 \\
4.3\end{array}$ & $\begin{array}{c}37 \\
2.2 \\
28 \\
1400\end{array}$ & 15 \\
\hline $\begin{array}{l}\mathrm{Al} \\
\mathrm{Cr} \\
\mathrm{Cu} \\
\mathrm{Mn}\end{array}$ & Urine & $\mathrm{Pd}+5 \% \mathrm{H}_{2}$ & $\begin{array}{l}0.06 \\
0.05 \\
0.08 \\
0.06\end{array}$ & $\begin{array}{l}- \\
- \\
- \\
-\end{array}$ & 16 \\
\hline $\begin{array}{l}\mathrm{Cr} \\
\text { Mo } \\
\mathrm{V}\end{array}$ & Bismuth tellurite optical crystals & - & $\begin{array}{l}1.1 \\
4.9 \\
6.7\end{array}$ & $\begin{array}{l}7.5 \\
20 \\
58\end{array}$ & 17 \\
\hline $\begin{array}{l}\mathrm{Cd} \\
\mathrm{Pb}\end{array}$ & Foodstuffs & $\mathrm{NH}_{4} \mathrm{H}_{2} \mathrm{PO}_{4}+\mathrm{Mg}$ & $\begin{array}{l}0.04 \\
0.93\end{array}$ & $\begin{array}{l}1.5 \\
37\end{array}$ & 18 \\
\hline $\begin{array}{l}\mathrm{As} \\
\mathrm{Bi} \\
\mathrm{Sb} \\
\mathrm{Se} \\
\mathrm{Te}\end{array}$ & Water & $\mathrm{Ir}$ & $\begin{array}{c}0.82 \\
0.04 \\
0.26 \\
0.29 \\
-\end{array}$ & $\begin{array}{c}177 \\
91 \\
107 \\
90 \\
-\end{array}$ & 19 \\
\hline $\begin{array}{l}\mathrm{Cd} \\
\mathrm{Cr} \\
\mathrm{Cu} \\
\mathrm{Ni} \\
\mathrm{Pb}\end{array}$ & Potable and surface water & $\mathrm{Pd}+\mathrm{Mg}$ & $\begin{array}{c}0.1 \\
1 \\
1 \\
1 \\
1\end{array}$ & $\begin{array}{l}- \\
- \\
- \\
- \\
-\end{array}$ & 20 \\
\hline $\begin{array}{l}\mathrm{Mo} \\
\mathrm{V}\end{array}$ & Seawater & $\mathrm{NH}_{4} \mathrm{H}_{2} \mathrm{PO}_{4}+\mathrm{Mg}$ & $\begin{array}{l}0.35 \\
0.32\end{array}$ & $\begin{array}{l}- \\
-\end{array}$ & 21 \\
\hline $\begin{array}{l}\mathrm{Cr} \\
\mathrm{Ni}\end{array}$ & Serum & - & $\begin{array}{l}0.05 \\
0.2\end{array}$ & $\begin{array}{l}- \\
-\end{array}$ & 22 \\
\hline $\begin{array}{l}\mathrm{Cd} \\
\mathrm{Pb}\end{array}$ & Blood & $\mathrm{NH}_{4} \mathrm{H}_{2} \mathrm{PO}_{4}$ & $\begin{array}{l}0.2 \\
4.5\end{array}$ & $\begin{array}{l}- \\
-\end{array}$ & 22 \\
\hline $\begin{array}{l}\mathrm{Cd} \\
\mathrm{Pb}\end{array}$ & Urine & $\mathrm{NH}_{4} \mathrm{H}_{2} \mathrm{PO}_{4}$ & $\begin{array}{l}0.06 \\
2.6\end{array}$ & $\begin{array}{l}- \\
-\end{array}$ & 22 \\
\hline $\begin{array}{l}\mathrm{Cu} \\
\mathrm{Mn}\end{array}$ & Seawater & $\mathrm{Pd}+\mathrm{Mg}$ & 0.070 .10 & $\begin{array}{l}1.5 \\
37\end{array}$ & 23 \\
\hline $\begin{array}{l}\mathrm{Cd} \\
\mathrm{Pb} \\
\mathrm{Co} \\
\mathrm{Cu}\end{array}$ & Soil and sediment & - & $\begin{array}{c}0.001 \\
0.1 \\
0.05 \\
0.02\end{array}$ & $\begin{array}{c}0.44 \\
22 \\
22 \\
35\end{array}$ & 24 \\
\hline $\begin{array}{l}\mathrm{Cd} \\
\mathrm{Pb}\end{array}$ & Whole blood & $\mathrm{Pd}+\mathrm{Mg}$ & - & $\begin{array}{l}- \\
-\end{array}$ & 25 \\
\hline $\begin{array}{l}\mathrm{Co} \\
\mathrm{Mn}\end{array}$ & Urine & $\mathrm{Mg}$ & $\begin{array}{l}0.18 \\
0.09\end{array}$ & - & 26 \\
\hline
\end{tabular}


$2.5 \mu \mathrm{g} \mathrm{L}^{-1}$ of $\mathrm{Cd}^{2+}+50 \mu \mathrm{g} \mathrm{L}^{-1}$ of $\mathrm{As}^{3+}, \mathrm{Pb}^{2+}$ and $\mathrm{Se}^{4+}$ in $0.1 \% \mathrm{v} / \mathrm{v} \mathrm{HNO}_{3}$, with and without the concomitant species, were used for the heating program optimization and for the interference studies. These solutions were prepared directly in the autosampler cups by dilution $(1: 1)$ of the stock reference solution, containing $5.0 \mu \mathrm{g} \mathrm{L}^{-1}$ of $\mathrm{Cd}^{2+}+$ $100 \mu \mathrm{g} \mathrm{L}^{-1}$ of $\mathrm{As}^{3+}, \mathrm{Pb}^{2+}$ and $\mathrm{Se}^{4+}$ in $0.1 \% \mathrm{v} / \mathrm{v} \mathrm{HNO}_{3}$, with blank or interfering solutions.

The permanent chemical modifier $250 \mu \mathrm{g} \mathrm{W}+$ $250 \mu \mathrm{g}$ Rh was obtained according to the thermal coating process described in the literature. ${ }^{28}$ The heating program was optimized with pyrolysis and atomization temperature curves in absence and presence of the mixture $250 \mu \mathrm{g} \mathrm{W}+$ $250 \mu \mathrm{g} \mathrm{Rh}$ as chemical modifier. The instrumental adjustments and the heating program for the graphite tube are showed in Table 2.

The influence of increasing amounts of $\mathrm{Na}^{+}, \mathrm{K}^{+}, \mathrm{Mg}^{2+}$, $\mathrm{Ca}^{2+}, \mathrm{Cl}^{-}, \mathrm{NO}_{3}^{-}, \mathrm{SO}_{4}{ }^{2-}$ and $\mathrm{PO}_{4}{ }^{3-}$ in the analytes' absorbance signals was verified. The concomitant amounts (cations and anions) added to the analytical reference solutions were based on cation concentration, ranging from 50 to $5000 \mathrm{mg} \mathrm{L}^{-1}$. The interference studies of cations were executed using $\mathrm{NO}_{3}{ }^{-}$and $\mathrm{Cl}^{-}$salts, while for anions were used only $\mathrm{Na}^{+}$salts.

Experimental measurements were made with at least three replicates and based on integrated absorbance throughout this work.

\section{Results and Discussion}

When ETAAS is used for mono-element determinations, all experimental and instrumental parameters are optimized for only one analyte. Consequently, the best optimized pyrolysis and atomization temperatures are used in the heating program, minimizing condensed- and gas-phase interference. ${ }^{3}$ On the other hand, the adoption of compromised conditions for multi-element determinations by SIMAAS are mandatory. The heating program temperatures and chemical modifier must be carefully selected to achieve the best atomization efficiency for all the analytes. In general, the most volatile analyte determines the pyrolysis temperature while the least volatile analyte determines the atomization temperature. Despite of these adverse temperatures, the use of a transversely heated atomizer with integrated platform offers optimum conditions for both volatile and non-volatile elements. ${ }^{3}$ Add to that, STPF conditions adoption and the use of an appropriate chemical modifier have guaranteed similar performance of SIMAAS in comparison to monoelement ETAAS. This fact reinforces that the success of any atomic absorption spectrometer for simultaneous determination depends on using STPF conditions.

\section{Simultaneous heating program optimization}

The characteristic masses $\left(m_{o}\right)$ and the best pyrolysis and atomization temperatures for $\mathrm{As}, \mathrm{Cd}, \mathrm{Pb}$ and $\mathrm{Se}$ obtained by SIMAAS in absence and presence of the $250 \mu \mathrm{g} \mathrm{W}+250 \mu \mathrm{g} \mathrm{Rh}$ are presented in Table 3 and compared with mono-element ETAAS data indicated in the literature. ${ }^{29,30}$ It can be observed an agreement between the results obtained by SIMAAS with those obtained by mono-element ETAAS (Table 3). The higher pyrolysis temperatures achieved for $\mathrm{Cd}, \mathrm{Pb}$ and $\mathrm{Se}$ using SIMAAS were probably due to the higher Rh mass deposited on the graphite tube surface $(250 \mu \mathrm{g})$. However, this data are in

Table 2. Spectrometer settings and heating program parameters for the multi-element detection of $\mathrm{As}, \mathrm{Cd}, \mathrm{Pb}$ and $\mathrm{Se}$

\begin{tabular}{|c|c|c|c|c|}
\hline \multicolumn{5}{|c|}{ Spectrometer setup } \\
\hline & Arsenic & Cadmium & Lead & Selenium \\
\hline Wavelength (nm) & 193.7 & 228.8 & 283.0 & 196.0 \\
\hline Bandpass (nm) & 0.7 & 0.7 & 0.7 & 0.7 \\
\hline Lamp current $(\mathrm{mA})$ & 380 & 200 & 450 & 290 \\
\hline Read time (s) & 4.0 & 2.0 & 3.0 & 4.0 \\
\hline \multicolumn{5}{|c|}{ Heating progam for the THGA } \\
\hline Step & Temperature $\left({ }^{\circ} \mathrm{C}\right)$ & Ramp (s) & Hold (s) & Argon flow rate $\left(\mathrm{mL} \mathrm{min}{ }^{-1}\right)$ \\
\hline \multicolumn{5}{|c|}{$10 \mu \mathrm{L}$ of sample or analytical reference solution injection } \\
\hline Drying I & 110 & 10 & 5 & 250 \\
\hline Drying II & 130 & 10 & 10 & 250 \\
\hline Pyrolysis & $650^{a}$ & 10 & 15 & 250 \\
\hline Atomization & $2200^{a}$ & 0 & 4 & 0 \\
\hline Cleaning & 2200 & 1 & 4 & 250 \\
\hline
\end{tabular}

${ }^{\mathrm{a}}$ Optimized condition for $\mathrm{As}, \mathrm{Cd}, \mathrm{Pb}$ and $\mathrm{Se}$ in presence of $250 \mu \mathrm{g} \mathrm{W}+250 \mu \mathrm{g} \mathrm{Rh}$ as permanent chemical modifier; Total program time: $69 \mathrm{~s}$; Injection temperature: $20^{\circ} \mathrm{C}$. 
Table 3. Characteristic masses $\left(m_{0}\right)$, pyrolysis $\left(\mathrm{T}_{\mathrm{p}}\right)$ and atomization $\left(\mathrm{T}_{\mathrm{a}}\right)$ temperatures for $25 \mathrm{pg} \mathrm{Cd}+500 \mathrm{pg} \mathrm{As}, \mathrm{Pb}$ and $\mathrm{Se}$ in $0.1 \% \mathrm{v} / \mathrm{v}$ $\mathrm{HNO}_{3}$ in absence and presence of $250 \mu \mathrm{g} \mathrm{W}+250 \mu \mathrm{g} \mathrm{Rh}$ as permanent chemical modifier

\begin{tabular}{lcccc}
\hline & & \multicolumn{3}{c}{ Chemical modifier } \\
\cline { 3 - 5 } Analyte & Parameter & None & $\mathrm{W}+\mathrm{Rh}^{\mathrm{a}}$ & $\mathrm{W}+\mathrm{Rh}^{\mathrm{b}}$ \\
\hline \multirow{3}{*}{ As } & $m_{0}(\mathrm{pg})$ & 74 & 35 & 39 \\
& $\mathrm{~T}_{\mathrm{p}}\left({ }^{\circ} \mathrm{C}\right)$ & 500 & 1500 & 1200 \\
& $\mathrm{~T}_{\mathrm{a}}\left({ }^{\circ} \mathrm{C}\right)$ & 2100 & 2200 & 2100 \\
\hline \multirow{3}{*}{$\mathrm{Cd}$} & $m_{0}(\mathrm{pg})$ & 1.2 & 1.8 & 1.1 \\
& $\mathrm{~T}_{\mathrm{p}}\left({ }^{\circ} \mathrm{C}\right)$ & 300 & 650 & 500 \\
& $\mathrm{~T}_{\mathrm{a}}\left({ }^{\circ} \mathrm{C}\right)$ & 1200 & 1400 & 1200 \\
\hline \multirow{3}{*}{$\mathrm{Pb}$} & $m_{0}(\mathrm{pg})$ & 25 & 43 & 30 \\
& $\mathrm{~T}_{\mathrm{p}}\left({ }^{\circ} \mathrm{C}\right)$ & 500 & 900 & 800 \\
& $\mathrm{~T}_{\mathrm{a}}\left({ }^{\circ} \mathrm{C}\right)$ & 1200 & 1600 & 1800 \\
\hline \multirow{3}{*}{$\mathrm{Se}$} & $m_{0}(\mathrm{pg})$ & 87 & 68 & 42 \\
& $\mathrm{~T}_{\mathrm{p}}\left({ }^{\circ} \mathrm{C}\right)$ & 400 & 1300 & 1200 \\
& $\mathrm{~T}_{\mathrm{a}}\left({ }^{\circ} \mathrm{C}\right)$ & 1800 & 2000 & 2000 \\
\hline
\end{tabular}

aResults for the multi-element determination of $\mathrm{As}, \mathrm{Cd}, \mathrm{Pb}$ and $\mathrm{Se}$ by SIMAAS; 'Results for the mono-element detemination $\mathrm{As}, \mathrm{Cd}, \mathrm{Pb}$ and $\operatorname{Se}(29,30)$.

discordance with previous work, which indicates that masses higher than $200 \mu \mathrm{g}$ are not recommended due to the sensitivity decrease (about $15 \%$ for each analyte). ${ }^{28}$

The higher characteristic masses for $\mathrm{Cd}, \mathrm{Pb}$ and $\mathrm{Se}$ in comparison with mono-element ETAAS (Table 3), can be related to the compromised conditions adopted for the simultaneous determination. The necessity to consider compromised adjustments imposes $650{ }^{\circ} \mathrm{C}$ as pyrolysis temperature, due to the low thermal stability achieved for $\mathrm{Cd}$ in presence of $\mathrm{W}+\mathrm{Rh}$.

The atomization temperatures for all analytes were also increased in presence of the $\mathrm{W}+\mathrm{Rh}$ permanent modifier (Table 3), for $\mathrm{Cd}\left(1400{ }^{\circ} \mathrm{C}\right)$ and $\mathrm{Pb}\left(1600{ }^{\circ} \mathrm{C}\right)$ were lower than those verified for $\mathrm{As}\left(2200^{\circ} \mathrm{C}\right)$ and $\mathrm{Se}\left(2000^{\circ} \mathrm{C}\right)$. The atomization temperature selection for the simultaneous heating program $\left(2200^{\circ} \mathrm{C}\right)$ was based on the As thermal behavior. This is also the maximum temperature recommended for the heating program in order to avoid loss of deposited Rh by vaporization..$^{28}$ The adoption of higher temperatures for the atomization and/or cleaning steps impairs the $\mathrm{W}+\mathrm{Rh}$ coating lifetime.

\section{Anion interference}

The effect of $\mathrm{Cl}^{-}, \mathrm{NO}_{3}{ }^{-}, \mathrm{SO}_{4}{ }^{2-}$ and $\mathrm{PO}_{4}^{3-}$ on the simultaneous atomization of $\mathrm{As}, \mathrm{Cd}, \mathrm{Pb}$ and $\mathrm{Se}$ are showed in Figure 1. The results were expressed as absorbance ratios calculated between absorbance signals with and without the anions.

The interference effect of $\mathrm{Cl}^{-}$in ETAAS has been largely
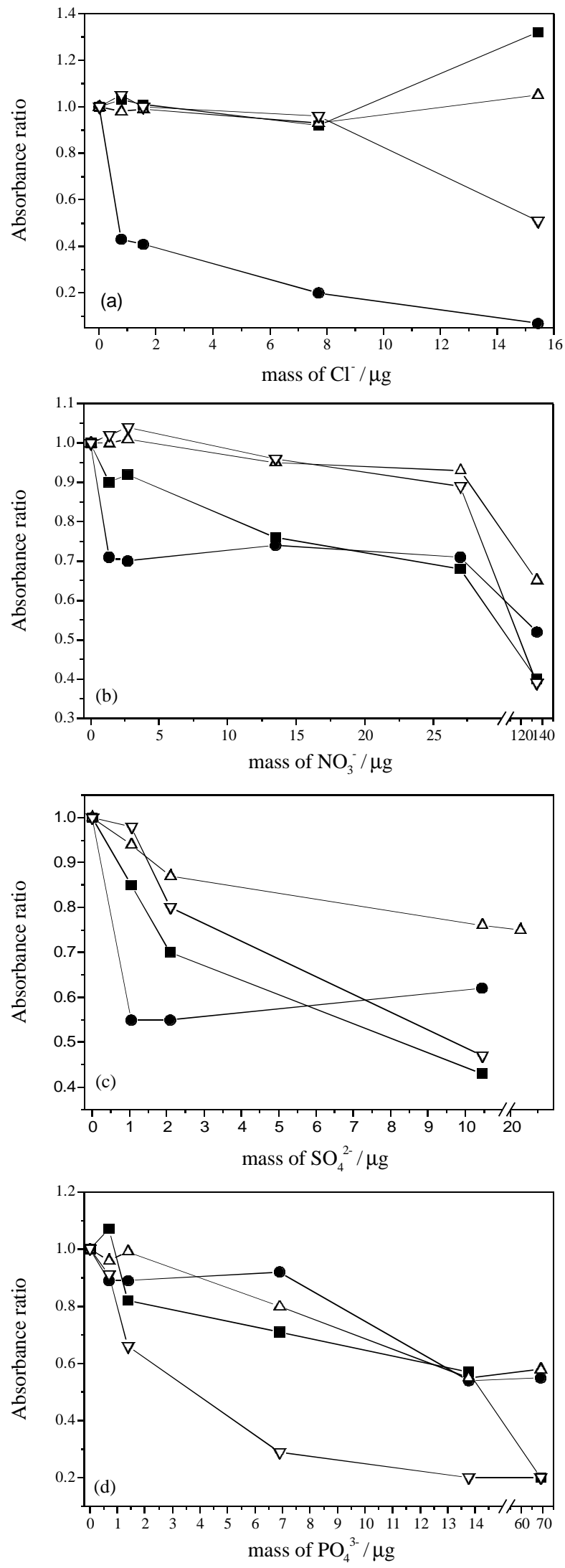

Figure 1. Interference effect of (a) $\mathrm{NaNO}_{3}$ (b) $\mathrm{NaCl}$, (c) $\mathrm{Na}_{2} \mathrm{SO}_{4}$ and (d) $\mathrm{Na}_{3} \mathrm{PO}_{4}$ on atomization of $25 \mathrm{pg} \mathrm{Cd}+500 \mathrm{pg} \mathrm{As}, \mathrm{Pb}$ and $\mathrm{Se}$ (ם $\mathrm{As},-\mathrm{Cd}, \triangle \mathrm{Pb}, \nabla \mathrm{Se}$ ). 
investigated. ${ }^{3}$ The use of chemical modifier is important to avoid loss of volatile chlorides during pyrolysis step. In this work, the pronounced effect observed from $0.8 \mu \mathrm{g} \mathrm{Cl}^{-}$ on $\mathrm{Cd}$ absorbance signal can be attributed to the volatilization of cadmium chloride during the pyrolysis step at $650^{\circ} \mathrm{C}$ (Figure 1a). Nevertheless, Cd loss was not observed when lower pyrolysis temperatures $\left(<500^{\circ} \mathrm{C}\right)$ were used. Probably, the formation and volatilization of $\mathrm{CdCl}_{2}$ occurred before the interaction between $\mathrm{Cd}$ and $\mathrm{Rh}$ on the graphite tube surface. It can be concluded that $\mathrm{Cl}^{-}$ions, even in low amounts, damaged the thermal stabilization obtained for $\mathrm{Cd}$ in presence of the $\mathrm{W}+\mathrm{Rh}$ as permanent chemical modifier. Similar behavior was observed for low masses of $\mathrm{NO}_{3}^{-}(1.3$ $\mathrm{mg}$ ) and $\mathrm{SO}_{4}^{2-}(1.0 \mathrm{mg})$, which also reduced the $\mathrm{Cd}$ absorbance signal (Figures $1 \mathrm{~b}-1 \mathrm{c}$ ). The increase of $\mathrm{Cl}^{-}, \mathrm{NO}_{3}^{-}$, $\mathrm{SO}_{4}^{2-}$ masses did not cause any expressive change in the $\mathrm{Cd}$ absorbance ratios. On the contrary, the initial decrease of the $\mathrm{Cd}$ ratio was not observed in presence of $\mathrm{PO}_{4}{ }^{3-}$ (Figure 1d), probably due to the increase in the thermal stabilization of this element. The synergistic effect between $\mathrm{W}+\mathrm{Rh}$ and $\mathrm{PO}_{4}{ }^{3-}$ was efficient to stabilize $\mathrm{Cd}$ at $650^{\circ} \mathrm{C}$. Cadmium and $\mathrm{Pb}$ form very stable oxyphosphorous compounds ${ }^{3}$ and, for this reason, $\mathrm{NH}_{4} \mathrm{H}_{2} \mathrm{PO}_{4}$ is usually used as chemical modifier for these elements.

The effect of $\mathrm{SO}_{4}^{2-}$ on As and $\mathrm{Se}$ was more pronounced than on $\mathrm{Pb}$ atomization (Figure 1c). For the latter, the effect of $\mathrm{Na}_{2} \mathrm{SO}_{4}$ is aggravated in strong acid solutions. ${ }^{32}$ The lower integrated absorbance observed for Se can be explained by molecular interference, which occurs due to the vaporization of $\mathrm{SO}_{4}^{2-}$ decomposition products, such as $\mathrm{SO}_{3}, \mathrm{SO}_{2}$, and $\mathrm{SO} .{ }^{33-35}$ Arsenic exhibited strong signal suppression in presence of the $\mathrm{SO}_{4}^{2-}$ (Figure 1c). This effects can be attributed to the interactions between $\mathrm{As}$ and $\mathrm{Na}_{2} \mathrm{SO}_{4}$ and the resulting decomposition products, particularly sulfide species. ${ }^{36}$

Selenium suffered more strong interference in presence of $\mathrm{PO}_{4}^{3-}$ (Figure 1d). Additionally, As was the most affected analyte by $\mathrm{NO}_{3}^{-}$(Figure $1 \mathrm{~b}$ ). It can be supposed that the low pyrolysis temperature adopted for the simultaneous heating program $\left(650^{\circ} \mathrm{C}\right)$, impaired the adequate formation of the atomic precursors for As.

\section{Cation interference}

The performance of $250 \mu \mathrm{g} \mathrm{W}+250 \mu \mathrm{g}$ Rh to overcome the interference caused by $\mathrm{Na}^{+}, \mathrm{K}^{+}, \mathrm{Mg}^{2+}$ and $\mathrm{Ca}^{2+}$ on the simultaneous atomization of $\mathrm{As}, \mathrm{Cd}, \mathrm{Pb}$ and $\mathrm{Se}$ atomization are showed in Table 4 . The results were expressed as absorbance ratios calculated between the absorbance signal with and without the cations.

In general, chloride salts caused more pronounced interference than nitrate salts. Cadmium was the most affected analyte, mainly in presence of alkaline ions (Table 4). The interference for all analytes was negligible only in

Table 4. Absorbance ratios for $25 \mathrm{pg} \mathrm{Cd}+500 \mathrm{pg} \mathrm{As}, \mathrm{Pb}$ and $\mathrm{Se}$ in presence of $\mathrm{Na}^{+}, \mathrm{K}^{+}, \mathrm{Mg}^{2+}, \mathrm{Ca}^{2+}$ as chloride and nitrate salts

\begin{tabular}{|c|c|c|c|c|c|c|c|c|c|}
\hline & & \multicolumn{8}{|c|}{ Absorbance ratio } \\
\hline \multicolumn{2}{|c|}{ Mass $(\mu \mathrm{g})$} & \multicolumn{4}{|c|}{$\mathrm{Cl}^{-}$salt } & \multicolumn{4}{|c|}{$\mathrm{NO}_{3}^{-}$salt } \\
\hline & & As & $\mathrm{Cd}$ & $\mathrm{Pb}$ & $\mathrm{Se}$ & As & $\mathrm{Cd}$ & $\mathrm{Pb}$ & $\mathrm{Se}$ \\
\hline \multirow{5}{*}{$\mathrm{Na}^{+}$} & 0.5 & 1.0 & 0.43 & 0.98 & 1.0 & 0.90 & 0.71 & 1.0 & 1.0 \\
\hline & 1 & 1.0 & 0.41 & 0.99 & 1.0 & 0.92 & 0.70 & 1.0 & 1.0 \\
\hline & 5 & 0.92 & 0.20 & 0.93 & 0.96 & 0.76 & 0.74 & 0.95 & 0.96 \\
\hline & 10 & 1.3 & 0.07 & 1.0 & 0.51 & 0.68 & 0.71 & 0.93 & 0.89 \\
\hline & 50 & - & - & - & - & 0.40 & 0.52 & 0.65 & 0.39 \\
\hline \multirow{5}{*}{$\mathbf{K}^{+}$} & 0.5 & 1.1 & 0.39 & 0.86 & 0.95 & 1.0 & 0.79 & 0.99 & 1.0 \\
\hline & 1 & 1.1 & 0.36 & 0.85 & 0.95 & 1.0 & 0.77 & 0.97 & 0.99 \\
\hline & 5 & 1.0 & 0.36 & 0.69 & 0.86 & 1.0 & 0.68 & 0.92 & 0.96 \\
\hline & 10 & 0.94 & 0.12 & 0.64 & 0.71 & 0.91 & 0.50 & 0.84 & 0.92 \\
\hline & 50 & - & - & - & - & 0.56 & 0.67 & 0.46 & 0.37 \\
\hline \multirow{5}{*}{$\mathrm{Mg}^{2+}$} & 0.5 & 0.97 & 0.89 & 0.96 & 0.89 & 1.0 & 0.93 & 0.99 & 0.98 \\
\hline & 1 & 0.99 & 0.79 & 0.89 & 0.96 & 1.1 & 0.96 & 1.0 & 1.0 \\
\hline & 5 & 1.0 & 0.70 & 0.78 & 1.0 & 1.0 & 0.95 & 0.96 & 1.0 \\
\hline & 10 & 1.1 & 0.38 & 0.62 & 1.0 & 0.98 & 0.84 & 0.95 & 0.98 \\
\hline & 25 & 1.1 & 0.05 & 0.40 & 1.0 & 0.87 & 0.86 & 0.95 & 0.88 \\
\hline \multirow{5}{*}{$\mathrm{Ca}^{2+}$} & 0.5 & 0.92 & 0.89 & 0.86 & 0.89 & 0.92 & 0.91 & 1.0 & 0.96 \\
\hline & 1 & 0.87 & 0.82 & 0.84 & 0.89 & 1.0 & 0.90 & 1.0 & 1.0 \\
\hline & 5 & 0.85 & 0.66 & 0.82 & 0.87 & 1.1 & 0.77 & 1.1 & 1.0 \\
\hline & 10 & 0.71 & 0.44 & 0.71 & 0.78 & 0.93 & 0.53 & 0.89 & 0.91 \\
\hline & 25 & 0.62 & 0.40 & 0.71 & 0.77 & 0.87 & 0.64 & 0.93 & 0.91 \\
\hline
\end{tabular}


Table 5. Analysis and recovery test results for the simultaneous determination of $\mathrm{As}, \mathrm{Cd}, \mathrm{Pb}$ and $\mathrm{Se}$ in non-potable water samples

\begin{tabular}{|c|c|c|c|c|c|}
\hline & & \multicolumn{4}{|c|}{ Concentration $\left(\mu \mathrm{g} \mathrm{L}^{-1}\right)$} \\
\hline & & As & $\mathrm{Cd}$ & $\mathrm{Pb}$ & $\mathrm{Se}$ \\
\hline \multirow[t]{3}{*}{ Dilution 1:10 } & Sample A & $23.3 \pm 10$ & $61.8 \pm 10$ & $382 \pm 11$ & - \\
\hline & Ref. Value & $21.6 \pm 3.2$ & $58.9 \pm 13.6$ & $296 \pm 51$ & - \\
\hline & Recovery (\%) & 91 & 85 & 86 & 105 \\
\hline \multirow[t]{3}{*}{ Dilution 1:20 } & Sample B & $260 \pm 21$ & $291 \pm 21$ & $501 \pm 81$ & $181 \pm 20$ \\
\hline & Ref. Value & $226 \pm 7$ & $235 \pm 5$ & $507 \pm 9$ & $190 \pm 15$ \\
\hline & Recovery (\%) & 96 & 106 & 98 & 108 \\
\hline
\end{tabular}

presence of $\mathrm{Mg}^{2+}$ as nitrate salt. For this reason, $\mathrm{Mg}\left(\mathrm{NO}_{3}\right)_{2}$ is usually used as chemical modifier alone or combined with other substances. When magnesium chloride was tested, the interfering effect was more pronounced for all analytes (Table 4). These results highlighted the interfering effect of chloride anion.

\section{Non-potable water analysis and figures of merit}

Two non-potable water samples from Quality Technologies Pty Ltd (Mount Isa, Australia) used for interlaboratorial calibration were analyzed using the optimized heating program (Table 2) and the mixture of $250 \mu \mathrm{g} \mathrm{W}+250 \mu \mathrm{g} \mathrm{Rh}$ as permanent chemical modifier. The results of the simultaneous determination of $\mathrm{As}, \mathrm{Cd}$, $\mathrm{Pb}$ and $\mathrm{Se}$ (Table 5) are in agreement with the interlaboratorial values (95\% confidence level). Addition and recovery tests showed results between $85 \%$ and $108 \%$ for all analytes. It was possible to determine $\mathrm{As}, \mathrm{Cd}, \mathrm{Pb}$ and Se simultaneously in non-potable water samples considering $1: 10$ and $1: 20$ as dilution factor.

Detection limits for As $\left(3.2 \mu \mathrm{g} \mathrm{L}^{-1}\right), \mathrm{Cd}\left(0.03 \mu \mathrm{g} \mathrm{L}^{-1}\right), \mathrm{Pb}$ $\left(0.70 \mu \mathrm{g} \mathrm{L}^{-1}\right)$, and $\mathrm{Se}\left(3.0 \mu \mathrm{g} \mathrm{L}^{-1}\right)$ were calculated based on the variability of the 10 blank solution measurements according to $3 \mathrm{~S}_{\mathrm{blk}} / \mathrm{m}$, where $\mathrm{S}$ corresponds to the blank measurement standard deviation and $\mathrm{m}$ is the calibration curve slope. Characteristic masses obtained for $\mathrm{As}, \mathrm{Cd}, \mathrm{Pb}$ and Se were $35 \mathrm{pg}, 1.8 \mathrm{pg}, 43 \mathrm{pg}$, and $68 \mathrm{pg}$, respectively. Under these optimized conditions, the performance of the $\mathrm{W}+\mathrm{Rh}$ permanent chemical modifier was acceptable until 250 heating cycles, when the loss of sensitivity for all analytes indicated the $\mathrm{W}+\mathrm{Rh}$ coating degradation. The same graphite tube was re-coated twice and their lifetime was increase to 750 heating cycles.

\section{Conclusions}

According to this study, the simultaneous determination of $\mathrm{As}, \mathrm{Cd}, \mathrm{Pb}$ and $\mathrm{Se}$ with the mixture of $250 \mu \mathrm{g} \mathrm{W}$ $+250 \mu \mathrm{g} \mathrm{Rh}$ as permanent chemical can be subject to interference effects in high saline matrices. The volatile analytes, such as $\mathrm{Cd}$, imposes low pyrolysis temperatures ( $<650{ }^{\circ} \mathrm{C}$ ) when multi-element determinations are executed by SIMAAS. The decomposition and volatilization of $\mathrm{Na}^{+}, \mathrm{K}^{+}, \mathrm{Ca}^{2+}$ and $\mathrm{Mg}^{2+}$ salts only occur when higher pyrolysis temperatures are adopted. With the pyrolysis temperature used in the heating program (650 ${ }^{\circ} \mathrm{C}$ ) concomitants are volatilized with analytes, increasing the interference processes. The negative interference observed for $\mathrm{As}, \mathrm{Cd}, \mathrm{Pb}$ and $\mathrm{Se}$ can be related to losses by volatilization, due to the inappropriate formation of intermetallic compounds and/or solid solution between the analytes and the permanent chemical modifier.

\section{Acknowledgments}

The authors thank Fundação Coordenação de Aperfeiçoamento de Pessoal de Nível Superior (CAPES) for C. S. Nomura's fellowship and Fundação de Amparo à Pesquisa do Estado de São Paulo for the financial support (FAPESP Processo 2001/07048-1) and for P. R. M. Correia's fellowship (FAPESP Processo 2001/02590-2).

\section{References}

1. Erickson, B.E.; Anal. Chem. 2000, 72, 543A.

2. Sneddon, J.; Farah, B.D.; Farah, K.S.; Microchem. J. 1993, 48, 318.

3. Welz, B.; Sperling, M.; Atomic Absorption Spectrometry, $3^{\text {rd }}$ ed., Wiley-VCH: Weinheim, FRG, 1999.

4. Farah, K.S.; Sneddon, J.; Appl. Spectros. Reviews 1995, 30, 351.

5. Slavin, W.; Manning, D.C.; Carnrick, G.R.; Atom. Spectros. 1981, 2, 137.

6. Correia, P. R. M.; Oliveira, E.; Oliveira, P. V.; Talanta 2002, 57, 527.

7. Correia, P. R. M.; Oliveira, E.; Oliveira, P. V.; Anal. Chim. Acta 2002, 458, 321.

8. A. Filho, V. R.; Fernandes, K. G.; Moraes, M.; Neto, J. A G.; Atom. Spectros. 2002, 23, 7.

9. Oliveira, A P.; Moraes, M.; Neto, J. A G.; Lima, E. C.; Atom. Spectros. 2002, 23, 39. 
10. Fernandes, K. G.; Moraes, M.; Neto, J. A G.; Nóbrega, J. A.; Analyst 2002, 127, 157.

11. Chen, C.; Danadurai, K. S. K.; Huang, S.; J. Anal. Atom. Spectrom. 2001, 16, 404.

12. Volynsky, A. B.; Wennrich, R.; J. Anal. Atom. Spectrom. 2001, 16, 179.

13. Oliveira, P. V.; Oliveira, E.; Fresenius J. Anal. Chem. 2001, $371,909$.

14. Freschi, G. P. G.; Dakuzaku, C. S.; Moraes, M.; Nóbrega, J. A; Neto, J. A G.; Spectrochim. Acta 2001, 56B, 1987.

15. Thomaidis, N. S.; Manalis, N.; Viras, L.; Lekkas, T. D.; Int. J. Environ. Anal. Chem. 2001, 79, 121.

16. Lin, T.; Huang, S.; Anal. Chem. 2001, 73, 4319.

17. Bencs, L.; Szakács, O.; Kántor, T.; Varga, I.; Bozsai, G.; Spectrochim. Acta 2000, 55B, 883.

18. Correia, P. R. M.; Oliveira, E.; Oliveira, P. V.; Anal. Chim. Acta 2000, 405, 205.

19. Murphy, J.; Schlemmer, G.; Shuttler, I. L.; Jones, P.; Hill, S. J.; J. Anal. Atom. Spectrom. 1999, 14, 1593.

20. Feuerstein M.; Schlemmer, G.; Atom. Spectros. 1999, $20,149$.

21. Su, P.; Huang, S.; J. Anal. Atom. Spectrom. 1998, 13, 641.

22. White, M. A; Panati, A.; Atom. Spectros. 1998, 19, 89.

23. Su, P.; Huang, S.; Spectrochim. Acta 1998, 53B, 699.

24. Hoenig, M.; Cilissen A.; Spectrochim. Acta 1997, 52B, 1443.

25. Viksna, A; Lindgren, E. S.; Anal. Chim. Acta 1997, 353, 307.
26. Iversen, B. S.; Panayi, A.; Camblor, J. P.; Sabbioni, E.; J. Anal. Atom. Spectrom. 1996, 11, 591.

27. Welz, B.; Schelemmer, G.; Mudakavi, J. R.; J. Anal. Atom. Spectrom. 1992, 7, 1257

28. Lima, E. C.; Krug, F. J.; Jackson, K.W.; Spectrochim. Acta 1998, 53B, 1791.

29. Barbosa Jr, F.; Lima, E. C.; Krug, F. J.; Analyst 2000, 125, 2079.

30. Lima, E. C.; Barbosa Jr, F.; Krug., F. J.; Tavares A.; Talanta 2002, 57, 177

31. Zanao, R. A.; Barbosa F.; Souza, S. S.; Krug, F. J.; Abdalla, A L.; Spectrochim. Acta 2002, 57B, 291.

32. Cabon, J. Y.; Le Bihan, A.; Spectrochim. Acta 1996, 51B, 619.

33. Cabon, J. Y.; Le Bihan, A.; Anal. Chim. Acta 1999, 402, 327.

34. Ming, N. Z.; Bin, H.; Bin, H. H.; Spectrochim. Acta 1994, 49B, 947.

35. Cabon, J. Y.; Fresenius J Anal Chem 2000, 367, 714.

36. Welz, B.; Schlemmer G.; J. Anal. Atom. Spectrom. 1986, 1, 119.

Received: February 20, 2003

Published on the web: January 19, 2004

FAPESP helped in meeting the publication costs of this article. 